\title{
Jane Camens
}

\section{Mirrors of Diversity, or Culture from a Petri Dish?: Products of Australian Writing Programs and a Yardstick of Contemporary Australian Fiction}

Devotion

Ffion Murphy

Fremantle Arts Centre Press, 2006

ISBN 1-92106-478-1

268pp. Pb. AUD27.95

The Concerto Inn

Jo Gardiner

University of Western Australia Press, 2006

ISBN 1-920694-79-X

202pp. Pb. AUD24.95

The Travel Writer

Simone Lazaroo

Picador-Pan Macmillan, Australia, 2006

ISBN 0-330-42256-1

310pp. Pb. AUD32.95

The Summons

David Whish-Wilson

Vintage-Random House, Australia, 2006

ISBN 1-74051-388-6

275pp. Pb. AUD23.95

The Best Australian Stories 2006

Robert Drewe (ed)

Black Inc, Australia, 2006

ISBN 1-86395-270-5

309pp. Pb. AUD27.95

Speaking at a writers' festival in September this year, the 2006 Man Booker prize winner Kiran Desai said that although her writer mother (Anita Desai) had imbued her with a passion for reading and a desire to write, she honed her craft in writing workshops. These served her to a point, after which she trusted herself [note 1]. Desai neither attributed her skill to writing programs, nor derided them.

Others at the event were less ambivalent about writing programs, some of which are not unlike writing workshops. One of Australia's largest international 
selling authors whispered, in confidence, knowing I was writing this piece, that the (Australian) publishers he knows are amazed when a good novel is produced by someone who has been through a writing program - saying it appeared despite the program, not because of it. [note 2]

Some authors must be hoodwinking their Australian publishers, because novels are being published by writers who have attended university writing programs. For those, like me, working towards a postgraduate degree, it might be useful to know that even Desai, the younger, had trouble finding a publisher for her prize-winning novel (Desai 2007). Bon courage.

Criticisms of writing programs, some of which have been cited in earlier issues of TEXT [note 3], are summed up at least in part by a former literary agent who decried academia as being like factories that knock the interesting edginess off writing and churn out look-alike products. [note 4]

Now is the litmus test. Each year at this time TEXT looks at some of the latest products of Australia's university writing programs. From these we might judge whether academia produces literary culture in a petri dish, or whether it nurtures more organic forms of writing. My subjective interest is how diverse and fresh the writing is. Is there a living heart beat in the work? Given the present lack of interest in the study of Australian Literature at universities, are university programs producing something new, interlacing old ideas with new ones, nurturing a new generation of writers who tap into the nation's contemporary rhythms, fingers on the keyboard of who we are now? Are they demonstrating the ability to enliven a tired discipline that is weighed down in bygone realities? I look especially to see if they reflect contemporary realities in our increasingly globalised and hybridised nation.

My own specific interest is the emergence, or not, of a new, unique 'contaminated' literature, a concept I borrow from Princeton professor of Philosophy Kwame Anthony Appiah, who puts the case for 'cultural contamination' [note 5] - adapting or adopting influences from elsewhere - as well as what he calls 'rooted cosmopolitanism'. Jonathan Freedman points out:

the term seems oxymoronic: to have roots is to be embedded in a specific history, nation or people; to be a cosmopolitan is to declare oneself a citizen of the world. For Appiah, however, these two are inseparable. Local histories, he reminds us, have themselves been shaped by the movements of peoples and their communal practices (let's not call them cultures) as old as human history itself. And - the point has special salience after 9/11 - one can pledge allegiance to one's country and still conceive of oneself in terms of global identities or universal values. (Freedman 2005)

The Australian writer Janette Turner Hospital is of the view that Australians are well placed to demonstrate a non-partisan rooted cosmopolitan perceptive. With reference to this, she told an audience that 'Only an Australian could write a novel like Geraldine Brooks's March that undercuts northern and southern chiverlettes about that (American civil) war' (Turner Hospital 2006). How rooted and/cosmopolitan, and/or contaminated is the new batch of writing from the writing programs?

A call from the Reviews Editor of TEXT to universities around the country has uncovered four new novels: Devotion by Ffion Murphy, The Summons by David Whish-Wilson, The Travel Writer by Simone Lazaroo, and The Concerto Inn by Jo Gardiner. These are the books I review here, although other novels 
have been published from the programs, including Chris Womersley's debut novel The Low Road, of which Debra Adelaide wrote in the Australian Literary Review:

The Low Road is such an impressive novel that it alone should silence forever those cranky critics of writing programs who pop up from time to time, whinging about university-generated fiction, wilfully ignorant of the fact that creative writing has been taught in universities (at least overseas) for as long as has the discipline that used to be called literature. (Adelaide 2007: 23)

Like Adelaide, as a fiction reader I want to 'go to places I've never been before' (Adelaide 2007: 23). It should be evident here that 'going to places' does not necessarily mean to different physical locales. One seeks the shift within. I have reviewed the four novels before me in the order of how successful I found them in taking me on such adventures.

As well as the novels, I look at the diversity of imagined worlds in The Best Australian Stories 2006, which is a useful barometer of what is being produced outside the academy, although some of the writers in the collection are associated with writing programs.

First, following the example of Indonesian poets I have heard read, I apologise at the outset if my reviews cause anyone to take umbrage. This, the Indonesians say, gives license to say what you like, even make some mistakes. In my case, I feel like the blushing curate who does not want to give offence when asked about the taste of his boiled egg. (He answers, 'It's good in parts'.). One would like to put the best possible spin on all the products of the discipline when one's own omelette has yet to be served, as one does not want to end up with egg on one's face.

The first two novels I discuss are competent, engaging narratives which challenge the reader by playing with structure, point of view, lyrical language, spaces between words, and emotional minimalism. These are also the novels which, ironically perhaps, are most likely to appeal to the wider commercial market - for instance, to the readers of women's magazines - because they dramatise women dealing with extreme reactions to universally familiar concerns: betrayal and depression.

In Devotion, by Ffion Murphy, Veronica lies in silence in a Perth hospital ward, suffering post natal depression throughout the novel. She refuses to nurse her son, delivered by caesarean section. She taps out her memories and immediate observations on an Apple laptop, recommended by her doctor. This is the scaffolding around which the backstory, the main story, is built. Gradually, through delusion, hallucinations and waves of memory, the real story comes to light. It is a story of Veronica's magnetic attraction in childhood to Sharny, an exciting new girl at school whose bohemian mother takes and allows liberties well beyond those permitted by Veronica's own middle class family. Veronica's illness seems to relate to her self-punishment for betraying Sharny. Her lengthy convalescence ends tragically, though the emotion is kept tightly controlled.

Murphy's writing is seductive and intelligent, requiring the reader to catch up, to read between the spaces, to put the puzzle together without hand-holding, as Sharny might have demanded of Veronica. Veronica's story is gradually revealed - a bit here, a bit there, interwoven with episodes from the present and this drip-feeding is compelling. The lid Murphy opens on a world of 
friendship among women, shared lovers and family jealousies is convincingly evoked. Murphy is a strong story-teller. This first novel suggests promise of a quality writer in the making. It does not attempt to enter new territory. In relation to my particular enquiry, the character of Vernoica is neither 'rooted' nor cosmopolitan. If some are born with a solid sense of identity, and others achieve it, poor Veronica's identity is thrust upon her, tied up entirely with Sharny and Sharny's family. Indeed, she cannot remember her life before Sharny entered it.

The Concerto Inn by Jo Gardiner is the third work of fiction in the New Writing series by the University of Western Australia Press. The series was launched in 2005 to source novels and short prose from the nation's postgraduate writing programs. One worries a littler whether publication in this series ghettoises writers, suggesting that they could not find a publisher outside the academy. The same might be said, however, of Picador's decision to start an Asia list, or of any publishing venture with a focus on a particular area. When the decision is taken to start a new list, a publisher cannot wait to find a great work of staggering genius, but must run the press with the best of manuscripts to which they have access.

Jo Gardiner is a poet and the lyricism of her prose shines through on every page. The title of her novel refers to an imagined or real scene of adultery and betrayal, the description of which echoes one of the masterpieces of Chinese fiction, Dream of the Red Chamber. 'Inside, just opposite the entrance, there was a carved screen wall. There was no one about. He led me through passageways to a red chamber where he said I could stay the night' $(22,49)$.

Gardiner's narrative moves through a cosmopolitan landscape, from Hong Kong, to the Blue Mountains and Sydney, to Italy, Paris and back in time to Australia again. The focus of the narration shifts between two sisters, Isabelle and Madeline, who both flee Australia, escaping emotional baggage, and hiding their identities.

Gardiner's depiction of Isabelle's life in Hong Kong is evocative and convincing of lived experience. Isabelle discovers the city like a tourist, gradually moving into its rhythms, inhaling its polluted air with the love of an addict. Isabelle lives a lonely, alienated life as the jilted partner of an unfaithful writer in residence at Hong Kong University. But as her story unfolds and the fictive dream turns into a nightmare of revenge and murder, the plot becomes less credible, less like lived experience. When Isabelle burns the house in Australia she shared with her partner Philippe, shoots him dead in the middle of his book launch, and then rises phoenix-like from the ashes of her past into Wonderland realms of an idealised love affair in Italy, one questions the credibility of such occurrences. At the murder scene we are expected to accept without further explanation that 'The hysterical crowd has noticed neither Isabelle's departure, nor the arrival of forgiveness.'

Gardiner discomforts the reader by narrating the early section of Isabelle's story in the first person and addressing the entire section directly to Isabelle's partner, Philippe.

You left Katoomba before me and travelled to Guangzhou and the conference... You were standing behind the barrier, your hands in your pockets. At first you did not see me. When I kissed you, there was a strange new scent... (7)

The effect is like finger-pointing and hissed accusations, like watching the narrator rub the face of a dog in its own mess. The device seems to tie the 
narrative to a peculiarly personal experience. From page 27 this device is dropped and the story is related in close third person, staying intimately with Isabelle's thoughts until page 93 when the focus switches to Madeline in Paris. Again, a story of betrayal, revenge, murder and escape is repeated, though with different characters at an earlier time. This second story does not inform the first.

Unlike Isabelle, whose suffering is intense, Madeline and her lover Xavier are lightly drawn, like the Madeline that Picasso drew in pastel, which Madeline comes face to face with. Her drama takes place in the backstory and for decades since she has tried to unmake herself, to hide who she is, disassociating herself from Australia, although it is precisely what she hates in herself - her accent and her association with her country - that Xavier loves. Xavier loves her not despite her Australian identity, but because of it, although it is just a little hard (for this reviewer) to believe that a 'true' Frenchman in Paris loves to drink a Coonawarra Merlot. Perhaps this raises the thorny notion of 'French values' and whether there are, or should be, such a thing as 'Australian values'. Both Madeline and Isabelle are cosmopolitan, but neither are rooted in identity. By the narrative's end they do not reconcile with themselves, but love reflections of themselves in each other.

Gardiner concludes with a brief return to Isabelle who turns to look behind at the sound of a bell, repeating Robert Lowell's last line: I bell thee home (202). The clang in the reader's ear is a little too loud, and I would have thought advisors in a writing program, or an editor, might have pointed this out. The clang occurs more than once. It is not entirely clear either who 'thee' is: the memory of Philippe, perhaps, who was originally addressed in second person, or the sister in Paris who is cleaved from the same stuff as Isabelle.

The next two novels are more ambitious, more sophisticated and ultimately more rewarding. These are novels in which the theme is larger than the individual characters who play out the dramas, the personal politics of the novels having wider political applicability. They are in this sense bigger books (not in size, but in subject and political scope) which Miriam Sved mentioned as among the characteristics critics tend to want to see in writing from writing programs, certainly from research higher degree programs which are expected to add something to existing knowledge. These next two novels could have been couched as comfortably within other disciplines, one within history and Linguistics (specifically, the language of persuasion) and the other in the area of cultural studies and globalisation. To my mind they support Miram Sved's proposition that we are already seeing a kind of 'literary ecology' emerging from writing programs in the form of novels 'tracing the byways of globalisation in private lives' and telling us who we are. She writes:

...university creative writing, located within a diversity of academic departments and engaged through shared environment and sometimes course structure with intellectual currents flowing from women's studies, postcolonialism, queer studies, etc, might foster this kind of literary ecology. (Sved 2006)

Robert Dixon said something similar in a speech in February 2007 on taking up the Sydney Chair of Australian Literature from Elizabeth Webby. This is now the only permanent chair of Australian literature in Australia. He assured his audience that the end is not nigh for Australian literature, only that it needs to find new directions: 
Developing intra-disciplinary connections within English and adopting transnational perspectives may offer an opportunity to re-connect the national literature - and our publishing about it to world contexts. (Dixon 2007)

The new quality writing coming from writing programs will be the new Australian Literature, because experience in North America is likely to be repeated here. Forty years ago, North American English departments included few living practitioners of the art of making literature. Those teaching the then new discipline of creative writing had to argue that the understanding and appreciation of literature could be enhanced by having practitioners teach the art.

It was a radical notion at some institutions, and positions for writers in many departments were hard-won... By offering classes in creative writing, academe has, ironically, reclaimed an aspect of literary study that it had divested when its humanities departments became specialized... With the acceptance of creative writing programs, departments of literature have restored their original, enabling scope: the study and practice of both the creative and critical literary acts.

(Fenza 2007)

What I am saying is that creative writing program outputs can save literary studies in Australia by importing inter-disciplinarity and cosmopolitanism, or a variant of it such as already exists within the Transforming Cultures Research Centre at the University of Technology, Sydney, and the Humanities Research Centre at the Australian National University which recognises the importance of establishing dialogue between the humanities and the natural and technological sciences, and the creative arts.

The Travel Writer is Simone Lazaroo's third novel and one that will increase her already well-established reputation as an outstanding writer of fiction. The Travel Writer is published by Picador, not as part of Pan Macmillan's new Asian fiction series, although it would have been a fine addition to the new list. Lazaroo was born in Singapore but has lived in Australia since 1963. She has already won numerous prizes for her fiction.

Lazaroo draws from a richly imagined and extensively researched universe, bringing to life the mixed-race world of Malacca, just after Independence ('but before my mother was wise'). Although nominally independent, the former colony lingers under British influence. In that melting pot of humanity, it is not only the British, Chinese and indigenous Malays who live separately and together, but also the children of Portuguese sailors and the mixed-blood Portuguese who add a unique flavour to the smells and textures of community life, a unique language, and the Portuguese songs of fate and longing. Lazaroo takes us into the protected world of a Eurasian girl, the narrator's mother, Ghislaine de Sequeira, who falls in love with a travel writer, whom she imagines will take her away from her in-between world of mixed identities. Eurasians are considered the equivalent of untouchables, except for their prostitutes whom the English use as 'sleeping dictionaries'. They translate one world to another, which is what Lazaroo also does, taking her readers from one reality into another.

Told parallel with Ghislaine's story is that of her daughter, the narrator Isabelle, who is intrigued by the rich diversity of her hybrid roots and who pieces together Ghislaine's story for a writing tutor while her mother lies dying in a London hospital. Lazaroo's tale embraces, entangles and breathes huskily into 
the ears of readers sagas of love and desire, of yearning, of sex misinterpreted as love, and ultimately a search for self and wholeness. Lazaroo shares secret recipes, the pigeon language, wisdom, customs and strict Catholic codes of conduct in a unique and dying community.

Lazaroo's rich postcolonial novel should resonate among Australians of a certain generation who looked, and still look in some cases, to Britain to set the standards by which quality is judged. The Travel Writer is more than a book about two Eurasian women from South East Asia. Malacca's hybrid society and the characters' post-colonial angst might be a metaphor for Australia today as we become increasingly hybridised and globalisation, borrowing, adapting and adopting from different cultures on the way to defining a society with a unique identity, finding one's 'true self' (as Ghislaine would say).

The Summons, the first novel by David Whish-Wilson, anticipates a strong future for this writer who demonstrates that he has read widely, researched solidly, and thought boldly. Set in Berlin between the First and Second World War, the protagonist is a wearied war veteran living in bohemian poverty, although he is also a reputed historian. Herr Dr Paul Mobius is one of Germany's foremost authorities on witchcraft persecutions. He is pursued by a manipulative former friend, Flade, now an officer in the SS. For reasons of security and the Nazi fascination with pagan religion, the New Army has a special interest in the methods of torture administered to witches. Flade and his superiors hunt down Mobius. They seek ways to sanction state torture through ideology and pagan practices.

One does not have to stretch one's mind too far to see an analogy between this historical fact-based novel and current political propagandas, justifying political expediency with the backing of spiritual right-doing and calls to tradition. One of Mobius's catchcries is: 'We do not look within ourselves to divine the future, but to our past' (79).

In the course of the novel two summonses arrive. The first is from the Reich Commission for the Scientific Registration of Hereditary and Constitutional Disorders, seeking to take into custody an intellectually handicapped boy, Carl, whom Mobius is close to. Fleeing with Carl and hiding him from the authorities, Mobius meets and falls in love with a woman, Monkia with whom he enjoys a late-life relationship. The second summons does not come until the end of the book.

My only difficulty with this novel is that it cranks up with excruciating slowness, having raised the expectation early in the story that something significant is going to happen. That something does not occur until the penultimate chapter. Mobius is summoned to travel to Westphalia where he enters a Gothic castle which is where the Reich's SS leaders are holding a series of seminars with eminent members of Germany's academic community, historians and scientists alike. There, Mobius witnesses horrors that raise the prospect of devastating consequences for Carl, and hears meaning in language turned on its head, including one currently familiar line of rhetoric, 'There can be no freedom without security!' (225). Mobius makes an Orwellian observation about the language used in the speeches, musing that 'every sentence was like a tunnel blocked with words, strings of clever-sounding nonsense tied into thick knots that fell at his feet and were still' (225).

Whish-Wilson has already had a novella short-listed for the Australian/Vogel literary award and one expects this novel or his future work to win him the acclaim he deserves, especially given his wide-ranging interests. He has recently completed a teaching engagement at the University of the South 
Pacific, has expressed interest in joining with writers in the Asian region, and is preparing to teach at the Centre for Aboriginal Studies, Curtin University.

Finally, I come to the collection of short fiction selected by Robert Drewe for The Best Australian Stories 2006. Drewe writes in his Introduction: 'Here in abundance they (readers) will find contemporary life in all its anxiety - a subject shunned of late by the Australian literary novel, with its obsession with the past and the bush' (x).

Three of the four novels I have reviewed here are not obsessed with an Australian past. The sisters in The Concerto Inn came out of a sheep property in the Bush, and most of the narrative devoted to Madeline does look back at this, but the women have moved on, living transnational lives. Drewe chose stories wanting to reflect 'diversity', yet to this reviewer the voices and concerns are mostly familiar, the range of imaginative universes and points of view disappointingly limited, compared with the scope of work attempted by at least two of the four novels reviewed here.

One asks again while reading this collection, what role fictional narrative plays in reflecting and defining identity? And, how is Australian identity reflected here? Do the writers demonstrate a sense of rooted cosmopolitanism? Some do.

Of the stories that stand out memorably for me, one is Paddy O'Reilly's 'Like the World's an Armchair' about a flight into fantasy by a woman abandoned with young children in the country, escaping into a make-believe world in which she has a lover with a Harley. O'Reilly writes with just the right amount of pathos and humour.

Then I'll slowly lift my head and he'll be staring at me like that actor, George Clooney, the gorgeous one, stared into J.Lo's eyes in that film and I'll take a deep breath and say to him, Can you hang on five minutes while I drop the kids at the orphanage? (3)...

Harley man. It's the way those blokes lean back on the bike that does it for me. Like the world's their armchair. (7)

O'Reilly has also written exquisite short fiction set in Japan, though possibly not recently enough to be included in this volume.

Another, 'I So Do Not Want to Be Having This Conversation', is written by Frank Moorhouse with his trademark ear for dialogue, humour, and cynicism. The story, couched between references to literature and current affairs (personal and political) recounts a literary lunch and frustrated seduction in New York between the narrator, who declares himself a member of People Without Borders, and a younger, emotionally-veiled American woman, shocked by the prospect of revealing anything about her personal life.

To my amazement she'd now put a finger in each of her ears and was making a buzzing sound - buzzzzz - to block anything I might say and then said, laughing, 'Hell-low? Hell-low? I think you dropped out. (188)

The story talks to Moorhouse's shared concern about censorship and selfcensorship and the willingness of societies to go wilfully along with their own oppression.

'Barcelona Honours the Prostitute Maria Llopis' by John Bryson plunges readers into the world of a Spanish woman who recalls growing up under Franco and the myths told about him, as well as the secret joy of a crowd at 
watching Franco almost shot in front of their eyes. This richly referenced, densely-packed monologue demonstrates Bryson's ability to leave his terrestrial body behind and enter alternative universes, although it fits uncomfortably in the collection except to offer greater geographical diversity in terms of the whole. In terms of advancing a dialogue on the state of Australian literature, it demonstrates how uncontainable Australia's contemporary Literature Without Borders is.

Juxtaposed against Bryson's rich landscape is a sparse, polished and emotionally brittle story, 'Nhill', by Patrick West, in which a couple set out to find a salt lake in a barren Australian desert. The map through a desert terrain might be a map of a parched human heart that finds enough nourishment even in the most barren of circumstances. 'There was nothing mystical about the scene in the end. No unworldly presence suggested itself in the shallow water... All the same, it was a place (the lake, the sky, the whole sense of it all) that you didn't want to treat like more familiar places' (135).

Finally, and importantly for my own interests in writing 'contaminated' by increasing engagement with Asia, Tom Cho's amusing and unlikely story, 'Today on $\mathrm{Dr}$ Phil', stands out. It is the only piece within the selection by an Asian-Australian. Only one example of writing from an Asian perspective does not seem to adequately reflect what many of the new writers I read are now concerned with. It is largely because of this failure to seek out those new perspectives influenced by Asia that the volume as a whole disappoints this reviewer and fails, in my view, to deliver Drewe's hopes of reflecting diversity.

In the story, Cho's unnamed narrator and his Auntie Lien are appearing on a TV talk show program with a famed psychologist. The episode is called 'What Are You Really Mad At?' and Auntie Lien, who turns out to be a scholar of ancient Greek drama, says that the sadder she gets, the angrier she gets. The narrator muses that perhaps he can transform his own anger into creativity, but ponders the unlikelihood of this because he has a tendency to over-intellectualise. The stage eventually erupts into uncontrolled uproar, but the narrator takes a step back.

I take the time to intellectualise about Dollard et al's "Frustration-Aggression Hypothesis" and its subsequent behaviourist/neo-associationist reformulation by Berkowitz. Having considered this and its implications for research on factors affecting aggression, I become angry... (235)

There is an entertaining lesson here about over-intellectualisation and lack of spontaneity, which is one of the criticisms aimed at creative writing from universities [note 6]. Auntie Lien's expertise in Euripidean drama and the narrator's concerns informed by Dollard et al in fact raise the story to high comedy and defy stereotypes of who Auntie Lien and her nephew might be. Defying stereotypes is ultimately what this issue of Best Australian Stories does.

The 2006 edition of Best Australian Stories still leaves wide open the question: How does contemporary Australian literature reflect who we are? I do not think this the book we export abroad, saying that contemporary Australia is revealed here through stories. Some of the stories are cosmopolitan, but overall, as a collection, there is no sense of rootedness. Indeed, the collection reminds me of an attempt to cobble together stories about Hong Kong just after the handover from Britain to China, when writers had no clear sense of who they were any more. The editor of that collection, Martha Cheung, made the point that she did not offer the 'great revelation' on Hong Kong, that the stories she chose were 
unashamedly subjective - 'a collage rather than a representational painting' (Cheung 1998: ix). This might also be said about the 2006 edition of Best Australian Stories.

Perhaps, like cosmopolitan Hong Kong, Australian writers will demonstrate a more rooted sense of who we are when we finally shake off the psychological mantle of Britain and our links grow inevitably stronger with Asia, not just in the economic sphere. Creative writing programs with multidisciplinary interests, Asialink residency programs, the Arts Council's literary patronage, the Australian Research Council's willingness to fund research into Australia's place in the region, are all factors which can help nurture a new Australian literature that finally will strike chords for readers, as though they have met a friend abroad, expressing what it is to be Australian - even if that expression is not what John Howard might have wanted.

\section{Endnotes}

1. Kiran Desai was talking on a panel at the 2007 Ubud Writers Festival, Bali. The session was moderated by the editor of Asia Literary Review, Nury Vittachi. return to text

2. The writer asked not to be identified for fear of being dragged into a debate. Approached to teach writing workshops in Thailand he turned down the offer because he does not believe genius can be taught. return to text

3. See, for instance, Mary Rose Liverani's amusing and derogatory comments about 'the cool school of creative writing' in the Australian, cited by Miriam Sved in TEXT October, 2006 (Sved 2006). return to text

4. The former agent, who has moved on to other literary endeavours, expressed her opinion of writing from university writing programs while seeking new talent at the Ubud Writers Festival in Bali, September 2007. return to text

5. For an example of literary 'contamination' see Savige 2007. He writes: 'Paralleling economic developments, many Australian poets are connecting with Asia's diverse cultures and adding a new dimension to the national poetic tradition...' (Savige 2007: 22). return to text

6. Refer to the former literary agent cited in Note 4 above. return to text

\section{References}

Adelaide, Debra 2007 'Writers with readers in mind' The Australian Literary Review, 3 October, 21,23 return to text

Cheung, Martha P Y (ed) 1998 Hong Kong Collage, Oxford University Press, Hong Kong return to text

Desai, K 2007 Inheritance of Loss, Penguin, London return to text

Dixon, Robert 2007 'Australian Literature-International Contexts', a paper presented at 'New Reckonings: Australian literature - past, present and future', a conference in honour of Elizabeth Webby, University of Sydney, 2-3 February return to text

Fenza, David 2007 'About AWP: The Growth of Creative Writing Programs - A Brief History of AWP', AWP: The Association of Writers and Writing Programs, at http://www.awpwriter.org/aboutawp/index.htm (accessed 13 October 2007) return to text

Freedman, Jonathan 2005 "'The Ethics of Identity": A rooted cosmopolitanism', Review of K A Appiah The Ethics of Identity, The New York Times 12 June, at 
http:/query.nytimes.com/gst/fullpage.html?res=9F0DE4D71638F931A25755C0A9639C8B63 (accessed 13 October 2007) return to text

Savige, Jaya 2007 'Poets on the brink of Asia' The Australian Literary Review, 3 October, 22-23 return to text

Sved, Miriam 2006 'Products of the Discipline', TEXT 10, 2 October, at http://www.griffith.edu.au/school/art/text/oct06/sved.htm return to text

Turner Hospital, Janette 2006 Keynote address opening the Byron Bay Writers Festival, 4 August 2006, audio download available at http://www.abc.net.au/northcoast/stories/s1706674.htm return to text

Womersley, Chris 2007 The Low Road, Sceptre, Melbourne return to text

Jane Camens is pursuing a PhD in Creative Writing at Griffith University. She holds an MA in Creative Writing from the University of East Anglia. Her short fiction has been broadcast on the BBC World Service and published in literary journals and anthologies in the UK, Hong Kong and, most recently, in a bilingual Indonesian-Australian collection of creative writing. She is the founder of the Asia Pacific Writing Partnership.

\section{TEXT}

Vol 11 No 2 October 2007

http://www.textjournal.com.au

Editors: Nigel Krauth \& Jen Webb

Text@griffith.edu.au 